\title{
Study on Braking Sensation Based on Urban Working Conditions
}

\author{
Lanie Abi ${ }^{1}$, Tianji Feng ${ }^{2}$, Mingyue Zhou ${ }^{2}$, Jiajun Chen $^{2}$ \\ ${ }^{1}$ Jilin University, China \\ ${ }^{2}$ China Automotive Technology \& Research Center, China
}

\begin{abstract}
In this paper we researched the vehicle braking sense in three aspects of human, vehicle and environment and analysed their impacts on brake feeling. Through the real vehicle test we analysed the relationship among pedal force, pedal travel and deceleration. We used dynamometer test method to study the brake noise question. We designed a fixture which could imitate the suspension and made the test more close to the true level. Moreover we discussed how to establish the evaluation system of vehicle braking condition. Through real vehicle test of braking, we can test and record the brake system parameters in the braking process under urban working conditions. We recorded the brake frequency, the change of brake speed and brake disc temperature. Meanwhile, based on the analysis of braking condition, we put forward the index of brake load to reflect the city's traffic conditions. Experiment show that the braking condition and brake feel are related, braking condition also provides theoretical support for the design of brake system.
\end{abstract}

\section{The significance of braking sensation}

With the rapid development of China's economy, the domestic auto industry is developing rapidly with the development of economy. China's car ownership was second only to the United States, ranked second in the world. Along with the development of the automobile industry, the demand of consumer is more and more high, the performance of the braking system, has been put into a more and more important position. Now the type of brake system on the market is multifarious, the different model parameters of the brake parts match assembled together to become a set of braking system, then how to judge the merits of a set of brake system. As all of us know, the automobile manufacturing is to provide a means of transport to the consumer, obviously, under the premise of satisfy the security, breaking feeling of consumers is an important index to judge the braking system of the pros and cons. According to Andrew $\mathrm{J}$ et al study, we should study some factors, including the pedal force, the pedal stroke, the deceleration ${ }^{[1,2]}$, when we analysis braking condition, we need to focus on the characteristics of brake pedal feeling characteristics $^{[3,4]}$,as Jan Sendler et al study. We know that passenger car braking systems are generally hydraulic system, the pressure is very important to focus on pipeline ${ }^{[5]}$ as Joel Sanford et al study. Thebrake friction coefficient $^{[6,7,8,9]}$ is very importantas W. Y. Loh.R. H et al study. Through this study ${ }^{[10,11]}$, the automobile factory in the braking system design process, can fully take into account the braking feeling and urban conditions, clear product positioning. In the preliminary design process, the study can help to achieve the design of high efficiency, low cost and high quality products to make customer satisfy, also can let the designers know what parameters in the design process need to focus on. Study on brake noise, $\mathrm{K}$ Brent et $\mathrm{al}^{[12,13,14]}$, shows that many factor will influence the brake noise. There are many factors we should consider ${ }^{[15,16,17,18,19,20]}$ when we study noise. Urban conditions is very important for energy recovery, as Maizza $\mathrm{V}$ et al studies ${ }^{[21,22,23]}$. When we research the energy recovery, we should also take care of the parameters of vehicle ${ }^{[24,25,26,27,28]}$.

\section{Test method}

We recorded the data of pedal feeling, braking deceleration, wheel cylinder pressure, friction temperature changes of braking system, vacuum booster vacuum degree, vacuum booster start coordinates, brake noise, urban traffic conditions related parameters (initial braking speed, final braking speed and braking times) and so on. We will then analysis the relationship among these data. We will fully research on braking feeling influence related parameters.

\subsection{Brake feeling evaluation method}

Brake feel is the driver's subjective feeling in the braking process of vehicle mainly reflect through the pedal feeling and deceleration feeling, which pedal feeling refers to the braking system on the driver's foot reaction force and feeling of travel, represented by the pedal force and the pedal displacement. Feeling of moderation refers to the vehicle deceleration of the driver caused by the body inertia, visual and auditory feedback, braking 
deceleration characterization. In this paper we use the relationship between pedal feeling and deceleration feeling to study the characterization of vehicle braking. Their relationship is shown in Fig. 1 and Fig. 2.

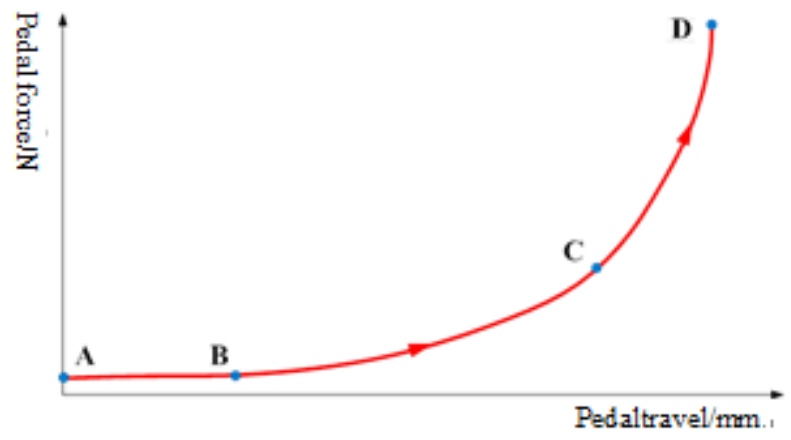

Figure1. Relationship between force and travel.

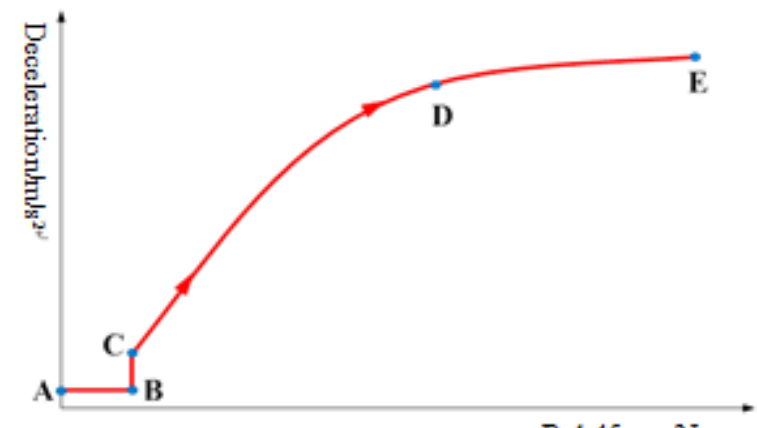

Pedalforce/N

Figure2. Relationship between force and deceleration.

\subsection{Brake noise test method}

In the process of working of the braking system, pedal and vacuum booster have a phenomenon of air travel. This will be reflected in the test results curve, the performance is the occurrence of curve step phenomenon, the slope of the curve and so on. Here, we will study the vacuum booster step point coordinates, the reasonable range of pedal free travel.

At the same time, we will study the temperature change of the friction plate, and the working noise of the brake system. The theoretical calculation of the noise is mainly through the brake test, the friction coefficient of the test process is mainly calculated by the following formula:

$$
\mu=\frac{10^{6} \cdot \mathrm{T}}{2 \cdot\left(\mathrm{P}-\mathrm{P}_{\mathrm{T}}\right) \cdot \mathrm{A}_{\mathrm{P}} \cdot \mathrm{r}_{\mathrm{eff}} \cdot \eta}
$$

- $\mathrm{T}$ : output torque, the unit is $\mathrm{N} / \mathrm{M}$

- $\mathrm{P}$ : brake pressure, the unit is $\mathrm{kPa}$

- $\mathrm{P}_{T}$ : braking actuating pressure, the unit is $\mathrm{kPa}$

- $A_{p}$ :piston area

- $r_{\text {eff }}$ :effective radius

- $\eta$ :efficiency

At present, there are two kinds of measuring methods of braking noise, which are vehicle measurement and bench measurement. Vehicle external environment have more noise interference on vehicle. Due to the effect of vehicle road test is affected by the weather, road conditions and driver's operation, repetition of some problem of braking conditions, especially difficult recurrence of the problems of brake noise. At this time, from the time and cost considerations, the bench test has a certain advantage. Bench test of the speed, brake pressure, temperature, humidity and other test conditions are more convenient and accurate control of the purpose. Compared with the road test, bench test has a unique advantage.

In the test of brake noise, we will compare the noise test results of the traditional fixture and the suspension clamp, so that our noise test results are more close to the real situation. Two types of fixture such as Fig. 3.

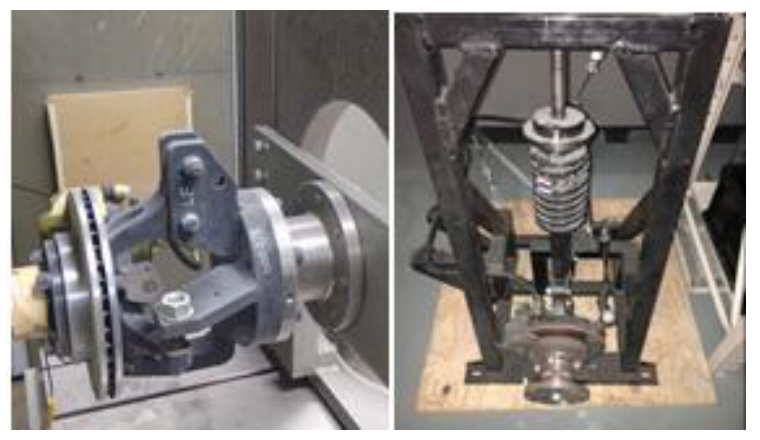

Figure3. Different types of fixtures.

\subsection{Evaluation of urban conditions}

We make statistics on all the relevant data of different cities in different road conditions, in order to fully reflect the working conditions of the braking system in different cities, and analysis the differences of working parameters. The processed data can provide the theoretical support for the service and the design process of the automobile factory. Particularly, in the current era, with the popularization of new energy vehicles, energy recovery become a very important research direction, in the research of urban traffic conditions we can not only on vehicle braking feeling research provide theoretical basis, and at the same time, it can provide a powerful data support for new energy vehicles energy recovery problem. The following is the calculation formula of the vehicle energy recovery rate:

$$
\eta=\frac{\sum_{i=1}^{n} \int_{t_{i-1}}^{t_{i}-2} U_{i-b a t} I_{i-c h g} d_{t}}{\sum_{i=1}^{n}\left(\frac{1}{2} m_{i-0}^{2}-m g f \int v d_{v}-C_{D} A_{p} / 2 \int v^{3} d_{t}\right)}
$$

- $U_{i-b a t}:$ Battery voltage

- $I_{i-c h g}$ :Charging current

- $v_{i-0}:$ Velocity difference

- V: Speed of braking process

From the above formula we can see that the molecular is motor energy recovery, the denominator is Recyclable energy theory. The theory of Recyclable energy is kinetic energy loss minus the rolling resistance loss of energy, and then minus the wind age loss of energy. In the process of energy recovery, rolling resistance and wind resistance energy loss in the vehicle design already decided, this paper mainly through urban conditions of vehicle speed difference to study the kinetic energy loss and energy recovery rate. On the basis of this, 
we put forward the index of brake load to reflect the city's traffic conditions:

$$
\mathrm{K}=\frac{\sum_{\mathrm{i}=1}^{\mathrm{n}}\left(\mathrm{V}_{\mathrm{bi}}^{2}-\mathrm{V}_{\mathrm{ei}}^{2}\right)}{2 \mathrm{~s}}
$$

where,

- $\mathrm{V}_{\mathrm{bi}}=$ The initial braking speed of $\mathrm{i}(\mathrm{m} / \mathrm{s})$

- $\mathrm{V}_{\mathrm{ei}}=$ The final braking speed of $\mathrm{i}(\mathrm{m} / \mathrm{s})$

- $\mathrm{S}=$ Travel mileage $(\mathrm{km})$

Because in each of the braking process, the loss of kinetic energy of the vehicle are not the same, in a period of time or mileage, the total amount of energy loss in one braking is not the same. To this end, we can know the braking frequency in a certain range, the initial speed of the braking process and the final speed, as well as the quality of the vehicle. The total kinetic energy of the braking loss is calculated, and the energy loss of unit mass in the unit mileage is obtained by dividing the quality and mileage of the vehicle, which is the braking load index K.

\section{Data acquisition}

\subsection{Data acquisition of pedal sensory}

Pedal feel objective test is through equipment (GPS vehicle speed sensor, pedal force sensor, pull rope displacement sensor and portable data acquisition instrument) to collect brake reducing speed, braking time, pedal, pedal stroke, pipeline pressure and velocity parameters, then the collected data were processed quasi synthetic curves. We can know the change process of the pedal force, pedal travel and pipeline pressure value of the test vehicle at different characteristics by curve. The test conditions of each test vehicle are cold state, and each test is carried out by multiple groups of braking, select the best of the three sets of data, the pedal force and pedal travel to the implementation of the average value calculation. Using MATLAB to collect and process the data collection, and then compare the drawing.

\subsection{Data acquisition of vehicle parameters}

We will record the vacuum booster coordinates (from stepping on the pedal to the vacuum booster began to boost the role of the process, we use the coordinates which are labelled with vacuum degree and the corresponding pedal travel).In the brake noise testing process, we will use the traditional fixture test, and by using suspension clamp test method to carry on the optimization, to make the braking system noise test more close to the real work

\subsection{Data acquisition of urban traffic conditions}

We use LINK3802 vehicle data acquisition system to collect urban traffic working conditions. Based on the test vehicle loading 3867-DG-X4 GPS velocity sensor, 3867DV-X1 vacuum sensor, 3867-DT-X2 brake pedal travel sensor, 3867-DF-X2 brake pedal force sensor, 3867-HT$\mathrm{X} 1$ temperature and humidity sensors, friction temperature sensor, acceleration sensor and other equipment to collect the data of target cities. The experiment was divided into four conditions: urban road condition, urban road The objective test results of 7 vehicles are shown in Table 2 as follows.

Congestion condition, suburban road conditions and the conditions of highway. In the test process, each braking of vehicle will trigger data acquisition system of the preset conditions, the data acquisition system will start recording data, data acquisition respectively: reducing speed, four wheel friction temperature, number of brake, braking initial velocity and terminal velocity, environmental temperature and humidity, vacuum negative pressure pump, pedal force and stroke, and record the friction plate abrasion.

\section{Data procession and test result}

\subsection{Comparison of subjective evaluation and objective test data}

Results of the subjective evaluation of the 7 test vehicles are summarized as shown in table 1.From table 1, we can see that the subjective evaluation score of A vehicle and $E$ vehicle is higher, and the evaluation results of $E$ in the 7 car is the best; $\mathrm{B}$ and $\mathrm{H}$ subjective evaluation score is low, in which the $\mathrm{H}$ subjective evaluation results are the worst. Need to add here: the test of the 7 test vehicles are the same type of passenger cars and the price in the same competitive range

Table1. Summary of subjective evaluation results

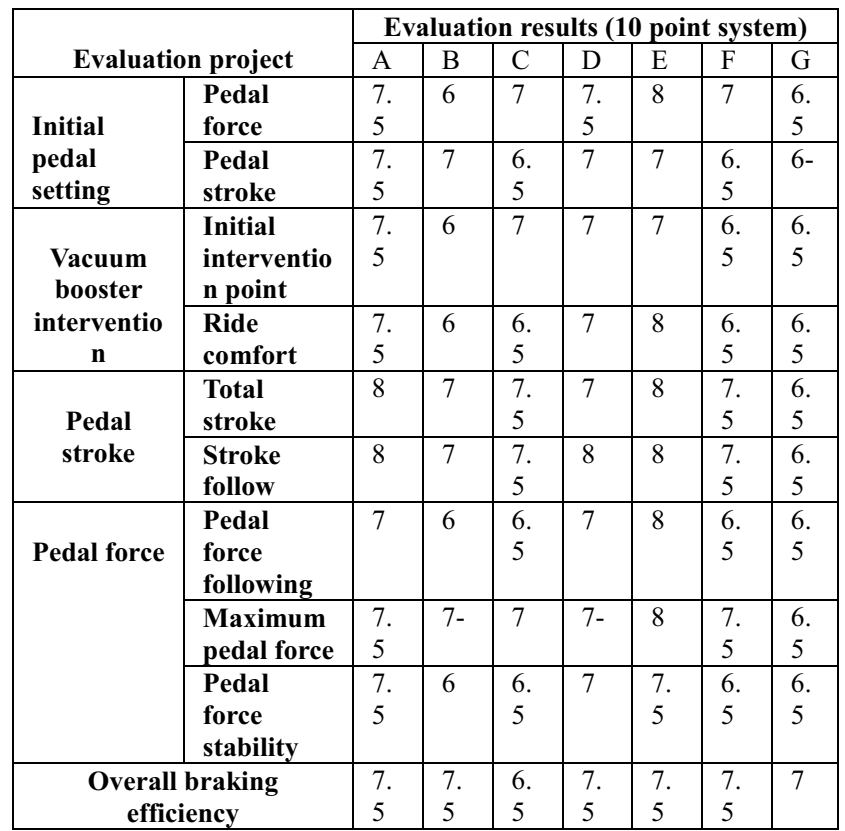

The objective test results of 7 vehicles are shown in Table 2 as follows.

Table2. Objective test results

\begin{tabular}{|c|c|l|l|l|l|l|l|l|}
\hline \multicolumn{2}{|c|}{ evaluating indicator } & $\mathrm{A}$ & $\mathrm{B}$ & $\mathrm{C}$ & $\mathrm{D}$ & $\mathrm{E}$ & $\mathrm{F}$ & $\mathrm{G}$ \\
\hline deceler & Pedal & 30 & 24 & 35 & 46 & 34 & 3 & 51 \\
ation & $\begin{array}{c}\text { stroke } \\
\text { 1 } \mathbf{m} / \mathbf{s} 2\end{array}$ & .7 & .9 & .4 & .2 & .7 & 5. & .8 \\
\hline
\end{tabular}




\begin{tabular}{|c|c|c|c|c|c|c|c|c|}
\hline & $\begin{array}{l}\text { Pedal } \\
\text { force } \\
(\mathrm{N})\end{array}$ & $\begin{array}{l}30 \\
.5\end{array}$ & $\begin{array}{l}44 \\
.5\end{array}$ & $\begin{array}{l}40 \\
.4\end{array}$ & $\begin{array}{l}33 \\
.4\end{array}$ & $\begin{array}{c}34 \\
.2\end{array}$ & $\begin{array}{l}4 \\
2 . \\
1\end{array}$ & $\begin{array}{l}39 \\
.8\end{array}$ \\
\hline \multirow[t]{2}{*}{$\begin{array}{l}\text { deceler } \\
\text { ation } \\
2 \mathrm{~m} / \mathrm{s} 2\end{array}$} & $\begin{array}{l}\text { Pedal } \\
\text { stroke } \\
(\mathrm{mm})\end{array}$ & $\begin{array}{l}35 \\
.8\end{array}$ & $\begin{array}{l}31 \\
.1\end{array}$ & $\begin{array}{l}42 \\
.1\end{array}$ & $\begin{array}{l}50 \\
.6\end{array}$ & $\begin{array}{l}39 \\
.1\end{array}$ & $\begin{array}{l}4 \\
0 . \\
7\end{array}$ & $\begin{array}{l}63 \\
.2\end{array}$ \\
\hline & $\begin{array}{c}\text { Pedal } \\
\text { force } \\
(\mathrm{N})\end{array}$ & $\begin{array}{l}36 \\
.5\end{array}$ & $\begin{array}{l}57 \\
.8\end{array}$ & $\begin{array}{l}46 \\
.3\end{array}$ & $\begin{array}{l}41 \\
.1\end{array}$ & $\begin{array}{l}41 \\
.2\end{array}$ & $\begin{array}{l}4 \\
8 . \\
6 \\
\end{array}$ & $\begin{array}{l}45 \\
.8\end{array}$ \\
\hline \multirow[t]{2}{*}{$\begin{array}{c}\text { deceler } \\
\text { ation } \\
3 \mathrm{~m} / \mathrm{s} 2\end{array}$} & $\begin{array}{l}\begin{array}{l}\text { Pedal } \\
\text { stroke } \\
(\mathrm{mm})\end{array} \\
\end{array}$ & $\begin{array}{l}41 \\
.8\end{array}$ & $\begin{array}{l}38 \\
.5\end{array}$ & $\begin{array}{l}48 \\
.2\end{array}$ & $\begin{array}{l}57 \\
.4\end{array}$ & $\begin{array}{l}45 \\
.4\end{array}$ & $\begin{array}{l}4 \\
5 . \\
8 \\
\end{array}$ & $\begin{array}{l}75 \\
.1\end{array}$ \\
\hline & $\begin{array}{l}\text { Pedal } \\
\text { force } \\
(\mathrm{N})\end{array}$ & $\begin{array}{l}48 \\
.7\end{array}$ & $\begin{array}{l}74 \\
.9\end{array}$ & $\begin{array}{l}56 \\
.7\end{array}$ & $\begin{array}{l}58 \\
.3\end{array}$ & $\begin{array}{l}56 \\
.9\end{array}$ & $\begin{array}{l}5 \\
9 . \\
7 \\
\end{array}$ & $\begin{array}{l}59 \\
.5\end{array}$ \\
\hline \multirow[t]{2}{*}{$\begin{array}{c}\text { deceler } \\
\text { ation } \\
4 \mathrm{~m} / \mathrm{s} 2\end{array}$} & $\begin{array}{l}\text { Pedal } \\
\text { stroke } \\
(\mathrm{mm})\end{array}$ & $\begin{array}{l}48 \\
.0\end{array}$ & $\begin{array}{l}45 \\
.0\end{array}$ & $\begin{array}{l}54 \\
.1\end{array}$ & $\begin{array}{l}63 \\
.4\end{array}$ & $\begin{array}{l}50 \\
.5\end{array}$ & $\begin{array}{l}4 \\
9 . \\
4\end{array}$ & $\begin{array}{l}83 \\
.1\end{array}$ \\
\hline & $\begin{array}{c}\text { Pedal } \\
\text { force } \\
(\mathrm{N})\end{array}$ & $\begin{array}{l}65 \\
.8\end{array}$ & $\begin{array}{l}88 \\
.0\end{array}$ & $\begin{array}{l}67 \\
.5\end{array}$ & $\begin{array}{l}77 \\
.1\end{array}$ & $\begin{array}{l}74 \\
.1\end{array}$ & $\begin{array}{l}7 \\
1 . \\
3 \\
\end{array}$ & $\begin{array}{l}80 \\
.5\end{array}$ \\
\hline \multirow[t]{2}{*}{$\begin{array}{c}\text { deceler } \\
\text { ation } \\
5 \mathrm{~m} / \mathrm{s} 2\end{array}$} & $\begin{array}{l}\text { Pedal } \\
\text { stroke } \\
(\mathrm{mm})\end{array}$ & $\begin{array}{l}53 \\
.0\end{array}$ & $\begin{array}{l}54 \\
.4\end{array}$ & $\begin{array}{l}57 \\
.9\end{array}$ & $\begin{array}{l}69 \\
.0\end{array}$ & $\begin{array}{l}54 \\
.7\end{array}$ & $\begin{array}{l}5 \\
2 . \\
7 \\
\end{array}$ & $\begin{array}{l}89 \\
.9\end{array}$ \\
\hline & $\begin{array}{c}\text { Pedal } \\
\text { force } \\
(\mathrm{N})\end{array}$ & $\begin{array}{l}81 \\
.0\end{array}$ & $\begin{array}{l}10 \\
9 .\end{array}$ & $\begin{array}{l}76 \\
.2\end{array}$ & $\begin{array}{l}98 \\
.5\end{array}$ & $\begin{array}{l}93 \\
.6\end{array}$ & $\begin{array}{l}8 \\
3 . \\
4 \\
\end{array}$ & $\begin{array}{l}98 \\
.7\end{array}$ \\
\hline \multirow[t]{2}{*}{$\begin{array}{l}\text { deceler } \\
\text { ation } \\
6 \mathrm{~m} / \mathrm{s} 2\end{array}$} & $\begin{array}{l}\text { Pedal } \\
\text { stroke } \\
(\mathrm{mm})\end{array}$ & $\begin{array}{l}58 \\
.1\end{array}$ & $\begin{array}{l}61 \\
.8\end{array}$ & $\begin{array}{l}62 \\
.3\end{array}$ & $\begin{array}{l}74 \\
.4\end{array}$ & $\begin{array}{l}58 \\
.4\end{array}$ & $\begin{array}{l}5 \\
6 . \\
6 \\
\end{array}$ & $\begin{array}{l}96 \\
.8\end{array}$ \\
\hline & $\begin{array}{l}\text { Pedal } \\
\text { force } \\
(\mathrm{N})\end{array}$ & $\begin{array}{l}98 \\
.5\end{array}$ & $\begin{array}{l}12 \\
5 .\end{array}$ & $\begin{array}{l}89 \\
.3\end{array}$ & $\begin{array}{l}12 \\
2\end{array}$ & $\begin{array}{l}11 \\
2\end{array}$ & $\begin{array}{l}1 \\
0 \\
3\end{array}$ & $\begin{array}{l}12 \\
6\end{array}$ \\
\hline
\end{tabular}

7 car comparison summary analysis diagram as shown Fig. 4 and Fig. 5.

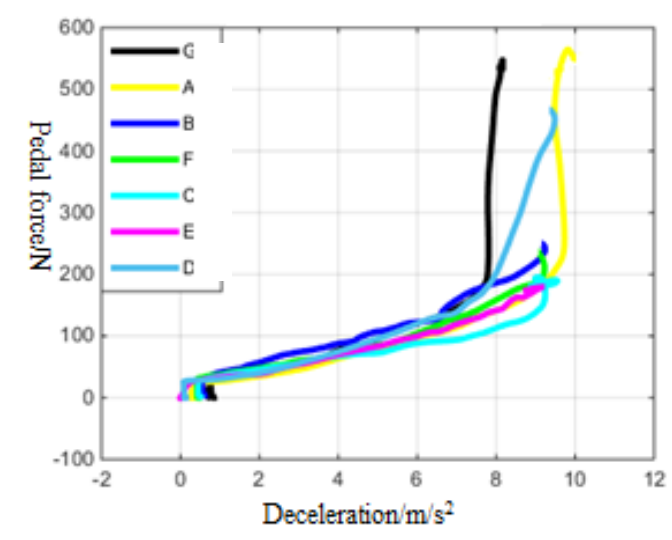

Figure 4. Relationshipamong force and udvel

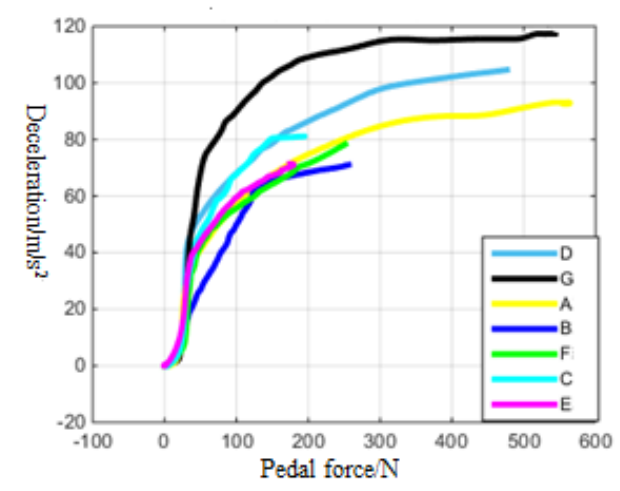

Figure 5. Relationshipamong force and deceleration

\subsection{Comparison of vehicle parameter data}

The key points of the objective test data are shown in Table 3.

Table 3. Objective test key point data

\begin{tabular}{|c|c|c|c|}
\hline \multicolumn{4}{|c|}{ Key objective test data } \\
\hline Objective & $\begin{array}{c}\text { Vacuum booster } \\
\text { intervention point } \\
\text { coordinates (a, } \\
\text { S,F) }\end{array}$ & $\begin{array}{c}0.3 \mathrm{~g} \\
\text { corresponding } \\
\text { to } S \text { and } F\end{array}$ & $\begin{array}{c}0.6 g \\
\text { corresponding } \\
\text { to } S \text { and } F\end{array}$ \\
\hline A & $\begin{array}{c}(0.41,20.4 \\
19.2)\end{array}$ & $(43.0,49.6)$ & $(58.5,96.7)$ \\
\hline $\mathbf{B}$ & $(0.56,13.9,30.4)$ & $(38.6,74.1)$ & $(62.4,123)$ \\
\hline $\mathrm{C}$ & $\begin{array}{c}(0.55,23.2, \\
27.3)\end{array}$ & $(49.7,56.2)$ & $(63.2,88.3)$ \\
\hline D & $\begin{array}{c}(0.09,20.4, \\
26.0)\end{array}$ & $(55.3,55.9)$ & $(72.5,120)$ \\
\hline $\mathbf{E}$ & $(0.43,22.0,23.4)$ & $(45.1,58.1)$ & $(57.8,114)$ \\
\hline $\mathbf{F}$ & $\begin{array}{c}(0.48,20.4, \\
30.0)\end{array}$ & $(46.2,60.1)$ & $(56.5,105)$ \\
\hline $\mathbf{G}$ & $\begin{array}{c}(1.21,13.9, \\
16.2)\end{array}$ & $(71.2,56.9)$ & $(96.5,120)$ \\
\hline
\end{tabular}

According to the expert's many years of design experience and reference materials, draw as shown in Table 4, a design value range (range of values due to the vehicle type)

Table4.Range of design values

\begin{tabular}{|c|c|c|c|c|c|}
\hline \multicolumn{6}{|c|}{ Design value range } \\
\hline \multicolumn{2}{|c|}{$\mathbf{g - F}$} & \multicolumn{3}{c|}{$\mathbf{g - S}$} \\
\hline $\begin{array}{c}\text { Intervention } \\
\text { point }\end{array}$ & $\begin{array}{c}\mathbf{0 . 3 g} \\
\text { travel } \\
(\mathbf{m m})\end{array}$ & $\begin{array}{c}\mathbf{0 . 6 g} \\
\text { travel } \\
(\mathbf{m m})\end{array}$ & $\begin{array}{c}\text { Intervention } \\
\text { point }\end{array}$ & $\begin{array}{c}\text { Pedal } \\
\text { force of } \\
\mathbf{0 . 3 g}(\mathbf{N})\end{array}$ & $\begin{array}{c}\text { Pedal } \\
\text { force of } \\
\mathbf{0 . 6 g}(\mathbf{N})\end{array}$ \\
\hline $\begin{array}{c}(0.05- \\
0.45,15- \\
25)\end{array}$ & $25-70$ & $40-85$ & $\begin{array}{c}(0.05,- \\
0.4,18-30)\end{array}$ & $35-90$ & $70-150$ \\
\hline
\end{tabular}

To do the test of automobile brake system, according to the test fixture, divided into car angle type, suspension type and bridge type test. The composition of the three types of fixtures can refer to Table 5, after the two types of clamps can be preloaded to the braking angle, to ensure that the vibration of the suspension components involved, closer to the real car, but the cost is higher.

Table 5. Different fixture components

\begin{tabular}{|c|c|c|c|}
\hline \multirow{2}{*}{$\begin{array}{c}\text { Component } \\
\text { requirements }\end{array}$} & \multicolumn{3}{|c|}{ Fixture level } \\
\cline { 2 - 4 } & $\begin{array}{c}\text { Steering } \\
\text { knuckle }\end{array}$ & $\begin{array}{c}\text { Suspension } \\
\text { form }\end{array}$ & $\begin{array}{c}\text { Full shaft } \\
\text { type }\end{array}$ \\
\hline Brake disc & $\mathrm{Y}$ & $\mathrm{Y}$ & $\mathrm{Y}$ \\
\hline friction material & $\mathrm{Y}$ & $\mathrm{Y}$ & $\mathrm{Y}$ \\
\hline $\begin{array}{c}\text { Caliper or wheel } \\
\text { cylinder }\end{array}$ & $\mathrm{Y}$ & $\mathrm{Y}$ & $\mathrm{Y}$ \\
\hline Bearing & $\mathrm{Y}$ & $\mathrm{Y}$ & $\mathrm{Y}$ \\
\hline wheel hub & $\mathrm{Y}$ & $\mathrm{Y}$ & $\mathrm{Y}$ \\
\hline Drive shaft & $\mathrm{Y}$ & $\mathrm{Y}$ & $\mathrm{Y}$ \\
\hline Control arm & $\mathrm{N}$ & $\mathrm{Y}$ & $\mathrm{Y}$ \\
\hline $\begin{array}{c}\text { Control arm } \\
\text { bushing }\end{array}$ & $\mathrm{N}$ & $\mathrm{Y}$ & $\mathrm{Y}$ \\
\hline Stabilizer bar & $\mathrm{N}$ & $\mathrm{Y}$ & $\mathrm{Y}$ \\
\hline \begin{tabular}{c} 
Shock absorber \\
\hline
\end{tabular} & $\mathrm{N}$ & $\mathrm{Y}$ & $\mathrm{Y}$ \\
\hline
\end{tabular}




\begin{tabular}{|c|c|c|c|}
\hline assembly & & $\mathrm{Y}$ & $\mathrm{Y}$ \\
\hline $\begin{array}{c}\text { Shock absorber } \\
\text { bushing }\end{array}$ & $\mathrm{N}$ & $\mathrm{N}$ & $\mathrm{Y}$ \\
\hline Auxiliary frame & $\mathrm{N}$ & $\mathrm{N}$ & $\mathrm{Y}$ \\
\hline $\begin{array}{c}\text { Auxiliary frame } \\
\text { bushing }\end{array}$ & $\mathrm{N}$ & $\mathrm{N}$ \\
\hline
\end{tabular}

After the test, the sound pressure level and the noise frequency of the noise scream are counted, and the results are shown in Fig. 6.

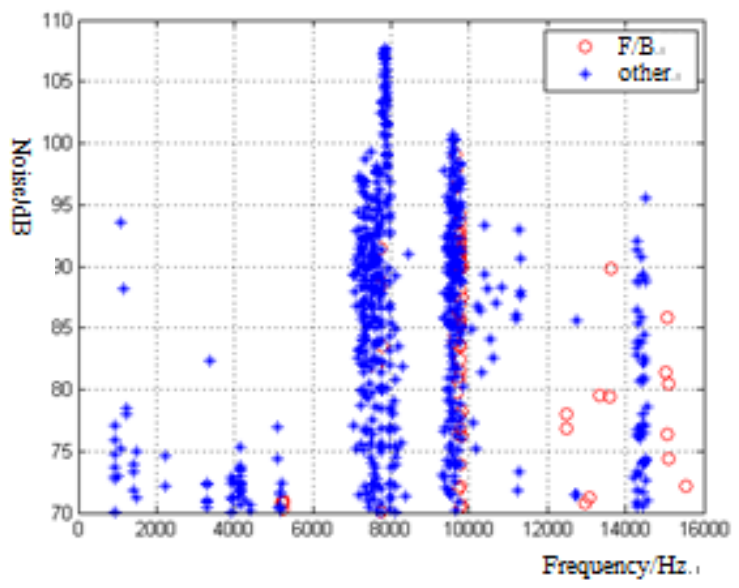

Figure 6. Relationship among frequency and noise.

Can be seen from the figure, when we use the car angle type clamp, the brake noise is mainly concentrated in the $7800 \mathrm{~Hz}, 9800 \mathrm{~Hz}$ and $14300 \mathrm{~Hz}$. And the same parts in the use of axle clamp, noise mainly concentrated in $2200 \mathrm{~Hz}, 3300 \mathrm{~Hz}$ and $9800 \mathrm{~Hz}$. This indicates that the braking noise is related to the suspension components, and the different types of fixture and suspension can cause the excitation of different frequency noises. $2200 \mathrm{~Hz}$ and $3300 \mathrm{~Hz}$ noise is low whistle, arises due to the mode coupling between parts, fixture impact on parts of the coupling state.

The braking test of different braking pressure on the brake system is carried out on the inertia test bench, and the test results are shown in Fig. 7.

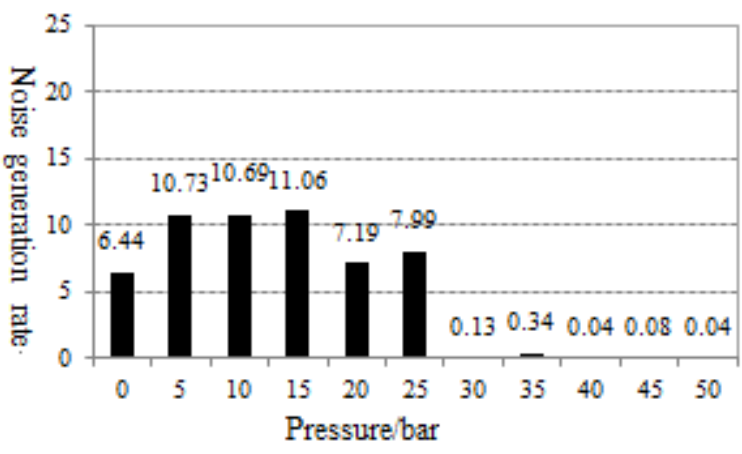

Figure7. Relationshipamongpressure and noise.

From the graph we can see that under different braking pressure, noise situation is different, the brake pressure in the range of $0-25 \mathrm{bar}$ is prone areas of brake noise, indicating that at low brake pressure brake noise happened tendentiousness larger. When the pressure is higher, the tendency of the brake noise is reduced, which is related to the contact stability between the friction surface and the brake disc. In the formulation of brake noise test specifications, more chapters should be set to low pressure brake.

The frequency and size of noise are different when the car is braking at high speed and low speed. This shows that the initial braking speed is also affected by the noise of the brake. In view of this situation, under the same condition to carry on the brake test to different vehicle speed, its result is shown in Fig. 8.

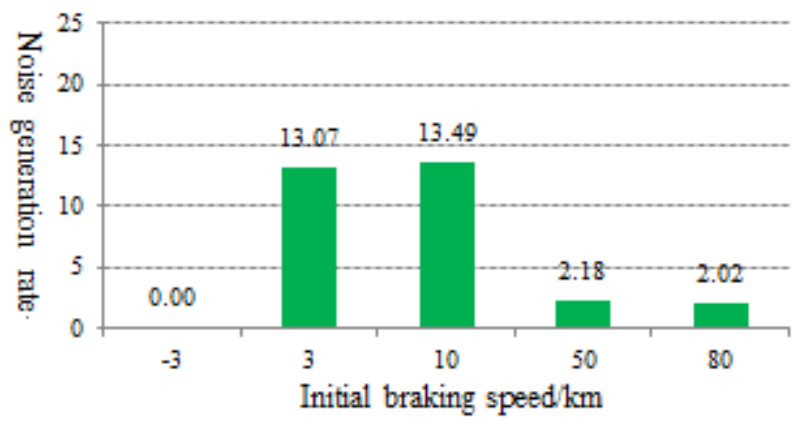

Figure 8. Relationshipamonginitial speed and noise.

When the vehicle speed is $10 \mathrm{kph}$ and $3 \mathrm{kph}$, we have the car brake, brake noise frequency is relatively high, Vehicle braking at $50 \mathrm{kph}$ to $80 \mathrm{kph}$, the car brake noise rate is significantly lower. From the user's point of view, brake noise is generally in low speed conditions such as traffic congestion. And working at high speed, the user brake less frequently the speed difference is not big. In the preparation of noise test specification, low speed conditions should be considered.

\subsection{Comparison of urban traffic conditions}

First of all, we'll process and analysis the data, then calculate these data we obtained, we will get the braking load index, according to different braking load index, we can know the different braking condition in different cities, the braking load index can reflect the loss of braking system of the city. The brake load index of different cities and the experimental data we processed are shown in Table 6 .

Table 6. Data processing results of different cities

\begin{tabular}{|c|c|c|c|c|c|c|}
\hline & $\begin{array}{c}\text { Travel } \\
\text { milea } \\
\text { ge }\end{array}$ & $\begin{array}{c}\text { Braki } \\
\mathbf{n g} \\
\text { times }\end{array}$ & $\begin{array}{c}\text { Decel } \\
\text { eratio } \\
\mathbf{n} \\
\text { mean( } \\
\mathbf{m} / \mathbf{s} \text { ) }\end{array}$ & $\begin{array}{c}\text { Pedal } \\
\text { force } \\
\text { average( } \\
\mathbf{N})\end{array}$ & $\begin{array}{c}\text { Maxim } \\
\text { um } \\
\text { pedal } \\
\text { stroke( } \\
\mathbf{m m}\end{array}$ & $\begin{array}{c}\text { Brake } \\
\text { load } \\
\text { index }\end{array}$ \\
\hline $\begin{array}{c}\text { Changch } \\
\text { un }\end{array}$ & 602 & 1147 & 1.55 & 17.49 & 60.96 & 73.8 \\
\hline Harbin & 587 & 1059 & 1.51 & 20.56 & 67.42 & 53.5 \\
\hline Dalian & 598 & 1377 & 1.26 & 16.76 & 61.7 & 74.2 \\
\hline Shenyang & 706 & 1144 & 1.43 & 17.02 & 63.43 & 66.2 \\
\hline
\end{tabular}

Here we compare the speed variation of the braking process by Fig. 9 and Fig. 10. 


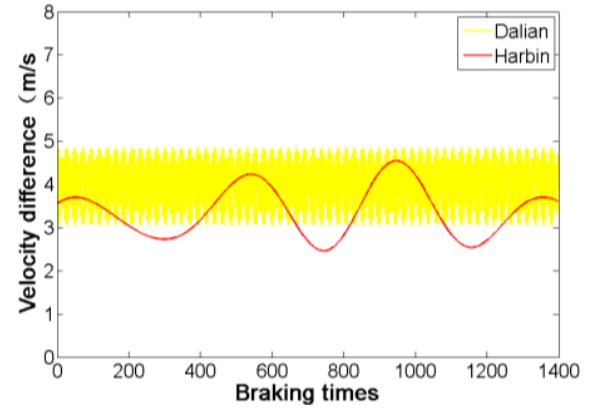

Figure 9. Velocity profile.

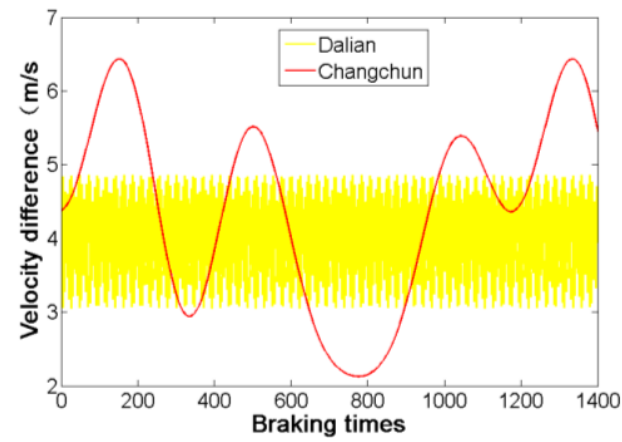

Figure 10. Velocity profile.

From Table 6 we already know that Dalian's brake load index is higher than that of Harbin, from Figure 9 we also see that the speed change of the braking process in Harbin is lower than that in Dalian. The speed change of the braking process is proportional to the energy change of the braking process, so the working strength of Dalian's braking system is higher than that of Harbin's braking system.

From Table 6 we know that the brake load index of Dalian and Changchun are very similar. Although the speed change during the braking process in Changchun is sometimes higher than in Dalian. From figure 10, by integrating the speed variation curves of the friction plate, we find that the results are similar, which indicates that the braking system of the two cities is relatively close to the working strength. But as we can see from Figure 7, the speed change in Changchun is significantly higher than that in Dalian. This shows that the driver's driving habits of Changchun significantly more intense than in Dalian. Changchun driver is more sensitive to the brake system.

The temperature change of the friction plate is shown in Fig. 11 and Fig. 12.

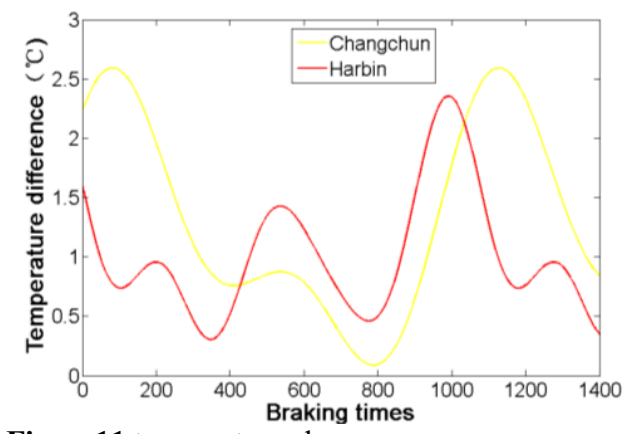

Figure11.temperature change

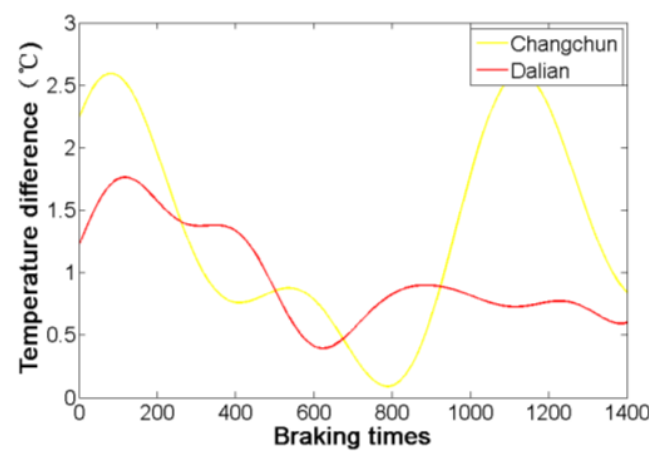

Figure12. Temperature change.

Fig. 11 is a comparison of the braking system temperature change between Changchun which has a higher braking load index and Harbin. From the figure, we can see that the temperature change of Changchun's braking system is more obvious than that of Harbin. At the same time, the temperature change of the friction plate in Harbin is more regular than that of the friction plate in Changchun. This shows that the use of the friction plate in Changchun is more intense than in Harbin, the loss of friction is greater than Harbin too. It can also be said that Changchun's driving habits are more intense than in Harbin.

Fig. 12 shows the comparison of the temperature change of the friction sheet between Changchun and Dalian, the braking load index of the two cities is close. It is not difficult to see from the diagram, the friction plate temperature of Changchun's braking system is more severe than that of Dalian (peak difference). But by integrating the temperature variation curves of the friction plate, we find that the results are similar, it shows that the energy consumption of the two cities in the braking condition is similar, brake system working strength is close. It is consistent with the results of the evaluation of the braking load index of two cities. But the difference of the peak difference shows the difference of driver's driving habits in two cities. Changchun's drivers prefer a more intense driving experience.

\section{Conclusion}

In the process of braking, we should collect brake feeling data and vehicle configuration parameters (pedal lever ratio, vacuum booster ratio, pipe diameter, friction, the friction coefficient) which have direct impact on vehicle braking feeling. The urban traffic condition should be considered, we will collect the traffic condition data (Including braking frequency, braking speed, friction temperature changes). Based on these data, we take brake noise tests of disc type brakes to acquire different noise under different working condition. Using different types of fixtures, brake noise performance were compared in different applying conditions. Noise occurrence was also studied in time domain. The influences of brake pressure, initial velocity and temperature on brake noise should be considered.. At the same time, the city's traffic conditions will certainly have an impact on the vehicle braking sensation. In particular, the braking condition of the 
vehicle also has a very important influence on the energy recovery of the new energy vehicle. Especially in the city, the speed change of the braking process directly reflects the change of the kinetic energy during the braking of the vehicle. It can be very intuitive to reflect the recycling of energy, to provide very important references for the design of new energy vehicles.

\section{References}

1. Andrew J. Day, Hon Ping Ho, Khalid Hussain. Brake System Simulation to Predict Brake Pedal Feel in a Passenger Car. SAE International, 2009, SAE200901-3043

2. Andrew J.Day.Break System Simulation to Predict Break Pedal Feel in Passenger Car[C].SAE 2009-01.

3. Jan Sendler, Ralf Trutschel, Klaus Augsburg. Methods of Evaluating and Developing Pedal and Brake Characteristics. ATZ Autotechnology, 2009, 111: 60-66.

4. Jan Sendler, Ralf Trutschel, Klaus Augsburg. Methods of Evaluating and Developing Pedal and Brake Characteristics. ATZ Autotechnology, 2009, 111: 60-66.

5. David Antanaitis, Mark Riefe, Joel Sanford. Automotive Brake Hose Fluid Consumption Characteristics and Its Effects on Brake System Pedal Feel. SAE Int. J. Passeng. Cars, 2010, 3(1): 113-130.

6. W. Y. Loh.R. H. Basch. Dynamic Modeling of Brake Friction Coefficients. SAE International, 2000, SAE2000-01-2753.

7. Satisfaction. Society of Automotive Engineers, 2003, SAE2003-01-3598: 1-6.

8. Rudilf Limpert. Brake Design and Safety. Warrendale: Society of Automotive Engineers, Inc, 1999.

9. Driver/Brake Pedal Under Real Road Conditions in View of Oncoming Brake-by-wire-systems. SAE International, 1999, SAE1999-01-2949: 1-9.

10. Rena Hecht Basch, Paul Sanders, Dale Hartsock. Correlation of Lining Properties with Brake Pedal Feel. SAE International, 2002, SAE2002-01-2602.

11. Andrea Fortina. Braking System Components Modelling. SAE International, 2003, SAE2003-013335 .

12. K Brent Dunlap, Michael A Riehle, Richard E Longhouse. An Investigative Overview of Automotive Disc Brake Noise [J]. Journal of Passenger, 1999, V108-6.
13. H R Mills. Brake squeak, Technical Report 9000 B [M]. Institution of Automobile Engineers, 1938.

14. Fosberry R AC, Holubecki Z. Third report on squeal of drum brakes [R]. MIRA Report No.1957/3.

15. R T Spurr. Atheoryofbrakesqueal, Proceedings of the Automobile Division [M]. Institution of Mechanical Engineers, 1961-1962(1) (1961) 33-52.

16. Bracken W J, Sakioka J K. Brake pad for reducing brake noise: US, US 4485898 A[P]. 1984.

17. Kusano M. Experimental study on the reduction of drum brake noise[C]. SAE851465, 1985.

18. Kamiya M, Kondo H, Sasaki S, et al. Vehicle brake system for preventing brake noise: US, US 20040212246 A1[P]. 2004.

19. Kamiya M, Kondo H, Sasaki S, et al. Vehicle brake system for reducing brake noise: US, US 20040183366 A1[P]. 2004.

20. Shin K, Brennan M J, J.-E. O H, et al. ANALYSIS OF DISC BRAKE NOISE USING A TWODEGREE-OF-FREEDOM MODEL[J]. Journal of Sound \& Vibration, 2002, 254(5):837-848.

21. Aldo Sorniotti Virtual and Experimental Analysis of Brake Assist Systems. SAE International, 2006, SAE2006-01-0477.

22. Zheng S Y, Jin C. Research on Engine Cranking Process in Downhill Braking Condition for an Electric Drive Underground Dump Truck[J]. Applied Mechanics \& Materials, 2013, 364:92-96.

23. Consonni S, Giugliano M, Massarutto A, et al. Material and energy recovery in integrated waste management systems: Project overview and main results[J]. Waste Management, 2011, 31(9-10):20572065.

24. Maizza V, Maizza A. Unconventional working fluids in organic Rankine-cycles for waste energy recovery systems[J]. Applied Thermal Engineering, 2001, 21(3):381-390.

25. Fernández I, Renedo C J, Pérez S F, et al. A review: Energy recovery in batch processes[J]. Renewable \& Sustainable Energy Reviews, 2012, 16(4):2260-2277.

26. Fernández I, Renedo C J, Pérez S F, et al. A review: Energy recovery in batch processes[J]. Renewable \& Sustainable Energy Reviews, 2012, 16(4):2260-2277.

27. Song X, Liu Z, Sun D D. Energy recovery from concentrated seawater brine by thin-film nanofiber composite pressure retarded osmosis membranes with high power density[J]. Energy \& Environmental Science, 2013, 6(4):1199-1210.

28. Stragier M G. BRAKE ENERGY RECOVERY SYSTEM: US, US 20110162903 A1[P]. 2011. 